Florence Nightingale Journal of Nursing

Florence Nightingale Hemşirelik Dergisi

FNJN Florence Nightingale Journal of Nursing 2019; 27(1): 17-25

Research Article

ISNN e-dergi: 2147-8686 • ISNN print: 2147-4923

\title{
The Effects of Nursing Education on Critical Thinking of Students: A Meta-Analysis
}

\author{
Filiz Kantek 이, Nezaket Yıldırım 우
}

DOI: $10.26650 /$ FNJN363168

ORCID IDs of the authors: F.K. 0000-0002-1524 9824; N.Y. 0000-0003-1000-6177

Akdeniz University Faculty of Nursing Department of Nursing Management, Antalya, Turkey

\section{Corresponding author:}

Filiz Kantek,

Akdeniz University Faculty of Nursing,

Department of Nursing Management, Antalya,

Turkey

E-mail: fkantek@akdeniz.edu.tr

Date of receipt: 06.12.2017

Date of acceptance: 11.072018

Cite this article as: Kantek, F. ve Yuldirum, N (2019). The effects of nursing education on critical thinking of students: A meta-analysis. FNJN Florence Nightingale Journal of Nursing, 27(1), 17-25

https://doi.org/10.26650/FNJN363168

\section{ABSTRACT}

Aim: The present study was aimed at investigating the effect of nursing education on the improvement of students' critical thinking skills in Turkey by using the meta-analysis method.

Method: The literature screening was carried out in online databases using the keywords "nursing", "student", "critical thinking", "Turkey" in English and their Turkish equivalents "hemşirelik", "öğrenci", "eleştirel düşünme", "Türkiye" respectively. Quantitative studies matching the inclusion criteria were included in the study. The number of the participants in those studies was 3792 (2183 first-year students and 1609 lastyear students). For the analysis of the data, the CMA (Comprehensive Meta-Analysis Software) statistical package program was used. While the $Q$ and I2 tests were used to test the homogeneity of the studies, the Classic Fail-Safe $N$ test and Kendall's Tau were used to test their publication bias. Fixed and random models were used to calculate the effect size.

Results: The results indicated that 10 studies met the inclusion criteria, and that the studies included in the study were heterogeneous and had no publication bias. The mean effect size was 0.114 at the $95 \%$ significance level [CL=0.087-0.440].

Conclusion: The results of the study indicated that nursing students were not able to develop their critical thinking skills and that there is a need for implementations to develop their critical thinking skills. This study will provide guidance for nursing school administrators and educators to develop critical thinking skills of nursing students.

Keywords: Critical thinking, meta-analysis, nursing, student, Turkey, year at school 


\section{INTRODUCTION}

Critical thinking is one of the competences necessary for nurses to effectively manage complex care needs in a rapidly changing environment (Carter, Creedy, \& Sidebotham, 2015). It is also an important training output in the accreditation and evaluation of nursing undergraduate and graduate programs (Kim et al., 2014; Yıldırım, 2010). Nurses use their critical thinking skills to respond to the problems they face in both personal and professional lives (Kim et al., 2014). Therefore, the better the critical thinking skills of nursing profession members are, the more effectively they can serve the public to protect and develop its health, and to increase its quality of life (Bapoğlu et al., 2011; İskender \& Karadağ, 2015).

Although there are several definitions for critical thinking, no consensus has yet been reached (Bilgiç \& Kurtuluş-Tosun , 2016; Güven \& Kürüm, 2006; Kaya, 2010; Seymour, Kinn \& Sutherland, 2003). Dewey defines critical thinking as in-depth thinking (Özmen, 2008; Riddell, 2007). Ennis (1991) defines critical thinking a "reasonable reflective thinking that is focused on deciding what to believe or do" (Ennis, 1991). Cüceloğlu defined critical thinking as "an active and organized mental process aimed at understanding ourselves and the events in our circle by applying what we learn, keeping in mind the thought processes of others, in the consciousness of our thought process" (Cüceloğlu, 1998).

Critical thinking can be improved through education (Kim et al., 2014; Profetto-McGrath, 2003). In order for education to develop critical thinking, it should be planned, and have teaching programs to develop critical thinking and educational environments that can gain students critical thinking experience (Bapoğlu et al., 2011; İskender \& Karadağ, 2015;
Kurnaz, 2011). Therefore, to gain individuals critical thinking skills is now considered to be mainly the responsibility of schools (Korkmaz, 2009). The knowledge, experience and skills acquired during the nursing education by nursing students who are the nurses of the future influence their decisions and practices in the professional life. This has led researchers to focus on nursing students in terms of critical thinking (Kong, Qin, Zhou, Mou, \& Gao, 2014).

The effect of nursing education on the development of students' critical thinking has been studied by many researchers. However, the results of these studies are not consistent with each other. While some studies have determined that nursing education affect the critical thinking (Bulut, Ertem, \& Sevil, 2009; Dil-Coşkun, 2001; Kantek, Öztürk \& Gezer, 2010; Oh et al., 2011; Öztürk \& Ulusoy, 2008; Shin, Lee, Ha \& Kim, 2006; Zaybak \& Khorshid, 2006), some other studies have reached the conclusion that nursing education does not affect the level of critical thinking (Çınar, Akduran \& Aşkın, 2012; Erdem, Bayat, Avcl, Tosun \& Seviğ, 2013; Kanbay, Aslan \& Işılk, 2013; Kermansaravi, Navidian, Kaykhaei \& Narouie, 2012; Martin, 2002). This contradictory situation in the results of those studies suggests that stronger evidence is needed to confirm the effect of nursing education on the development of critical thinking.

The literature review demonstrated that there are no meta-analyses related to the effect of nursing education on students' critical thinking skills. This present study was carried out to fill up this gap. The purpose of the present study is to evaluate the effectiveness of nursing education on the improvement of students' critical thinking skills in Turkey by using the meta-analysis method. Therefore, the study attempted to find an answer to the question "What is the effect size of nursing education on critical thinking levels of nursing students?" 
The results of the present study are expected to contribute to the better understanding of the effect of nursing education on critical thinking, and to provide new information to policy makers, school administrators and educators in planning the development of critical thinking skills of students.

\section{METHOD}

This meta-analysis followed the guidelines proposed by PRISMA standards of quality for reporting meta-analysis.

\section{Search Strategy}

The study team investigated studies on critical thinking skills of nursing students in Turkey. Databases of The Turkish Medical Index, National Thesis Center, Pubmed, Google Scholar, EBSCO Host, Web of Science were screened from their onset dates to July 2016. For the literature screening, the keywords "nursing", "student", "critical thinking", "Turkey" and their Turkish equivalents "hemşirelik", "öğrenci", "eleştirel düşünme", "Türkiye" respectively were used.

\section{Inclusion and Exclusion Criteria}

The two researchers independently of each other evaluated all the titles and abstracts of the potential articles identified by the first broad search. For the studies to be included in the meta-analysis, the following criteria were applied: (a) the study should be carried out in Turkey, (b) the sample should include nursing students, (c) it should have quantitative analysis data, (d) it should investigate the year at school variable, and (e) it should have sufficient statistical data to calculate the effect size. On the other hand, of the studies, those (a) published in languages other than
Turkish or English, (b) not having the full text, (c) not being an article and dissertation study (d) having measurement instruments without adequate psychometric properties were excluded from the study.

\section{Data Coding}

The data-encoding form was used for Data Extraction. On the data-encoding form, the title, author(s), publication year, publication type, publication language, study design, measurement instrument and critical thinking results based on the year at school variable (sample size, critical thinking scores, standard deviation) of each study were encoded. The reliability of the encoded data was established by comparing the coding of the first researcher with that of the second researcher. To prepare the data for the analysis, for the experimental group, the characteristics of the first-year students were loaded, and for the control group, the characteristics of the last-year students were loaded. Therefore, that the value of the effect size was positive indicates that the critical thinking level of the first-year students is higher, whereas that the value of the effect size was negative indicates that the critical thinking level of the last-year students is higher.

\section{Risk of Bias Assessment}

To assess the quality of the studies included in the meta-analysis, the "Quality Rating Scale" developed by Zangaro and Soeken (2007) was used. "The Quality Rating Scale" included 10 questions, with questions 1-9 consisting of yes or no responses, and question 10 consisting of three response options (low, moderate, and high) (Zangaro \& Soeken, 2007). Question 10 reflects a summary of the responses to questions $1-9$ as follows: a low 
response reflected a total of 4 yes responses, a moderate response 5-7 yes responses, and a high response 8 or 9 yes responses. All the studies were evaluated by both researchers using this scale, and there was 100\% agreement between the two researchers.

\section{Statistical Analyses}

The meta-analysis was performed using the CMA statistical package program. In the calculations, Hedges's g effect size, fixed and random effect models were used. While the $Q$ and $\mathrm{I}^{2}$ tests were used to test the homogeneity of the studies, the Classic Fail-Safe $\mathrm{N}$ test and Kendall's Tau were used to test their publication bias. In the evaluation of the mean effect sizes, the following classification was used: negligible effect $(\geq-0.15$ and $<0.15)$; small effect $(\geq 0.15$ and $<0.40)$; medium effect $(\geq 0.40$ and $<0.75)$; large effect ( $\geq 0.75$ and $<1.10)$; very large effect ( $\geq 1.10$ and $<1.45)$ and, huge effect ( $\geq 1.45)$ (Dinçer, 2014). Because the significance level was 0.05 in the included studies, for the significance level of the statistical tests, 0.05 was used in the current study too.

\section{Ethical Considerations}

Because the literature-screening model was used in the study, it has no direct effects on humans or animals. Therefore, ethics committee approval was not obtained.

\section{RESULTS}

Flow diagram summarizing the inclusion process of studies in the meta-analysis is presented in Figure 1. From the databases, 258 publications including articles and theses were accessed. Of the studies, nine did not have the full text and 82 had duplicates, 132 were not conducted in a student sample, 21 did not examine the year at school variable and 4 did not contain enough data. Thus, only 10 studies were considered appropriate for the meta-analysis. The selection of the studies for the meta-analysis was conducted separately by two researchers. The comparison of the two researchers' results revealed a 100\% agreement in terms of the inclusion criteria.

\section{Studies' Characteristics}

The number of the participants in the 10 studies included in the meta-analysis was 3792 (2183 first-year students and 1609 last-year students). The studies included in the metaanalysis were conducted between 2006 and 2016. All of the studies were in Turkish, and $90 \%$ of them were articles. While the California Critical Thinking Disposition Inventory was

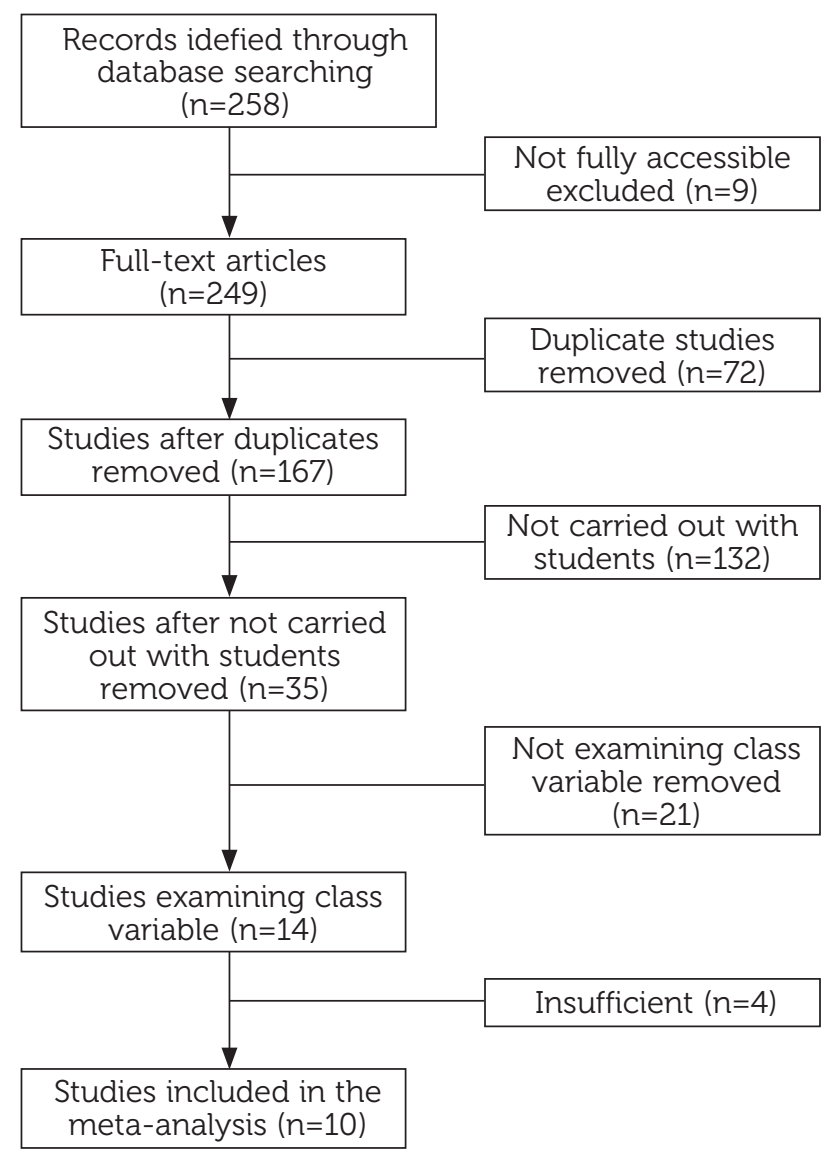

Figure 1. The flow chart of the inclusion process 
used in nine studies, the Watson-Glaser Critical Thinking Appraisal Scale was used in one study.

\section{Quality Assessment}

According to the quality assessment tool, the quality scores of the studies included in the meta-analysis ranged from 7 to 9 . Of the 10 studies, 2 received 9 points, 6 received 8 points, and 2 received 7 points. Therefore, it was decided that all the studies were of high quality.

\section{Homogeneity Tests}

Table 1 shows the results of the homogeneity tests applied to the studies in the review. The $Q$ value of these studies was 55.686, which suggested that these studies were heterogeneous when compared with the chi-square values of the table with a significance level of $95 \%$. As a result, mean

Table 1. The results of the homogeneity tests

\begin{tabular}{cccccc}
\hline & $\mathbf{Q}$ & $\mathbf{d f}$ & $\chi 2$ & $\mathbf{p}$ & $\mathbf{I}^{2}$ \\
\hline Critical Thinking & 55.686 & 9 & 16.919 & 0.000 & 83.838 \\
\hline
\end{tabular}

effect sizes were calculated in accordance with the random effects model.

\section{Publication Bias}

The Classic Fail-Safe $\mathrm{N}$ analysis indicated that the number of the publications required for the meta-analysis was one. The Tau coefficient was 0.377 and the $p$-value (2-tailed) was 0.128. Because the $P$ value was greater than 0.05, it was decided that there was no publication bias in the studies included in the meta-analysis.

\section{Effect Sizes}

The effect sizes of the studies conducted on nursing students' critical thinking skills are given in Table 2 . The effect sizes of the studies ranged from -0.342 to 0.773 .

Table 3 presents mean effect sizes of critical thinking among the first year and the last year students in accordance with random effects model. The mean effect size was 0.114 with a significance level of $95 \%$ [CL=0.087-0.440]. There was a statistically significant difference in favor of the first-year students.

Table 2. The effect sizes of the included studies

\begin{tabular}{lcccccc}
\hline & ES & SE & V & 95\% CI & Z & p \\
\hline Ozpulat \& Sivri, 2014 & 0.773 & 0.177 & 0.031 & $0.426-1.121$ & 4.361 & 0.000 \\
Eren-Fidancı et al. 2012 & 0.718 & 0.178 & 0.032 & $0.369-1.068$ & 4.032 & 0.000 \\
Çevik, Tekir, İnceler, \& Dikoğlu, 2014 & 0.090 & 0.149 & 0.022 & $-0.203-0.383$ & 0.601 & 0.548 \\
Sengül, 2010 & -0.241 & 0.103 & 0.011 & $-0.443-0.039$ & -2.336 & 0.019 \\
Senturan, 2008 & 0.036 & 0.045 & 0.002 & $-0.052-0.123$ & 0.806 & 0.402 \\
Ozturk \& Ulusoy, 2008 & -0.162 & 0.156 & 0.024 & $-0.469-0.145$ & -1.035 & 0.300 \\
Kanbay et al. 2013 & -0.235 & 0.184 & 0.034 & $-0.596-0.127$ & -1.272 & 0.203 \\
Zaybak \& Khorshıd, 2006 & -0.342 & 0.150 & 0.022 & $-0.635-0.049$ & -2.289 & 0.022 \\
Erdem et al. 2013 & 0.514 & 0.204 & 0.042 & $0.115-0.914$ & 2.522 & 0.012 \\
Bilgiç \& Kurtuluş Tosun, 2016 & 0.176 & 0.161 & 0.026 & $-0.139-0.492$ & 1.096 & 0.273 \\
\hline
\end{tabular}

ES: effect size; SE: standard error; V: variance 
Table 3 . The mean effect sizes and mean values according to random effects model

\begin{tabular}{ccccccccc}
\hline & $\mathbf{k}$ & $\mathbf{n}$ & $\mathrm{ES}$ & $\mathrm{SE}$ & $\mathbf{V}$ & $\mathbf{9 5 \%}$ CI & $\mathbf{Z}$ & $\mathrm{P}$ \\
\hline Critical Thinking & 10 & 3664 & 0.114 & 0.102 & 0.010 & $0.087-0.440$ & 1.111 & 0.267 \\
\hline
\end{tabular}

$\mathrm{k}=$ Number of studies ES: effect size; SE: standard error; V: variance

\section{DISCUSSION}

Critical thinking is one of the important outputs of nursing education (Kim et al., 2014; Yildirm, 2010). The inadequacy of critical thinking skills can affect the quality, efficiency and competence of the nursing service, professionalism and autonomy of the profession negatively (Bapoğlu et al., 2011; Durmuş-Iskender, \& Karadağ, 2015). It is necessary for the nurse to use critical thinking skills in order to be able to provide quality care in the clinic, to use hand skills, to provide autonomy, to maintain professionalism, to plan patient care and management (Küçükgüçlü $\delta$ Kanbay, 2011). It is clear that critical thinking is one of the basic skills for nursing. For this reason, it is important to determine changes in the critical thinking level of nursing students. In this present study, the effect of nursing education on students' critical thinking development in Turkey was investigated by using the meta-analysis method.

Our study results revealed that nursing education had a negligible effect on thestudents' critical thinking skills in Turkey. Many studies conducted in Turkey and in other countries have supported this finding. In Kaya, Şenyuva, \& Bodur's study (2016), no statistically significant difference was determined between the critical thinking levels of the students measured at the beginning and end of the academic year. In Çevik et al.'s (2014), and Şenturan and Alpar's (2008) studies, the difference between the critical thinking scores of nursing students from different grades were not statistically significant. Maynard (1996) investigated critical thinking skills of nursing students from the second year to the graduation year and found no improvement in their critical thinking skills. Azizi-Fini, Hajibagheri \& Adib-Hajbaghery, (2015) examined the changes in the critical thinking skills of nursing students in Iran. In their study, they determined no difference between the mean critical thinking scores of freshmen and senior nursing students. In a study conducted by Kim, Moon, Kim, Kim, Lee, (2014) in Korea, the critical thinking disposition score by year at school increased until the junior year, but declined in the senior year. A study conducted in Canada showed no increase across the four years (ProfettoMcGrath, 2003).

Among the important factors in providing students with critical thinking are trainers' critical thinking skills and experiences, education techniques used, preference of multiple choice questions in evaluation activities, lack of activities requiring analysis, synthesis and evaluation skills, and the number of students in a classroom (Akça \& Taşçl, 2009; Azizi-Fini et al., 2015; Kim \& Choi, 2014). The inadequacy of the nursing education in developing the critical thinking skills of nursing students in Turkey is thought to be the result of such problems as the teaching staff shortage and inadequate training and implementation environment caused by the uncontrolled increase in the number of nursing schools and student quotas per school in the last two decades in Turkey. The investigation of the nursing schools where the studies included in the meta-analysis were conducted revealed that the lecture approach which is characterized by teachers' verbally transmitting information directly to 
large groups of learners was still used and the teaching staff taught large student groups both in the classroom and in practice in these schools, which supports our view.

\section{Research limitations}

When the study results are interpreted, some limitations should be considered. This current study focuses on studies on the critical thinking skills of nursing students in Turkey. Therefore, it is not possible to generalize the results to all nursing education environments. Due to the lack of longitudinal studies investigating critical thinking skills of students, the meta-analysis data were obtained from cross-sectional studies. In the present study, critical thinking skills of nursing students were investigated in terms of "the year at school" variable. Therefore, it will be useful to conduct meta-analyzes in which the effects of different variables (learning environment characteristics, family characteristics, academic achievement, etc.) on students' critical thinking skills are investigated.

\section{CONCLUSION}

The results of the analysis revealed that nursing education in Turkey is inadequate for the improvement of students' critical thinking skills. Although the results of our study are not positive, they are of importance for nursing school administrators, academics and policy makers, because they indicate that nursing education needs revision. It should be recognized that the development of critical thinking could only be possible through the implementation of curricula and the provision of educational environments that support critical thinking. This may be possible only through the use of educational strategies that provide active participation of learners, such as group discussions, case studies, simulations, clinical reports, etc., which aim at producing knowledge and using knowledge instead of memorizing based learning.

Finally, It will be useful for nursing administrators and academicians to evaluate nursing education in terms of factors adversely affecting students' critical thinking skills, to apply strategies that increase the critical thinking tendency and to observe the effectiveness of these applications. Inclusion of international literature in studies to be conducted in the future will contribute to the generalizability of the results and will make it possible to understand cultural differences. In addition, there is a need to examine the effectiveness of initiatives aimed at improving students' critical thinking skills through metaanalysis.

Ethics Committee Approval: Authors declared that the research was conducted according to the principles of the World Medical Association Declaration of Helsinki "Ethical Principles for Medical Research Involving Human Subjects", (amended in October 2013).

Informed Consent: The literature-screening model was used in the study, it has no direct effects on humans or animals.

Peer-review: Externally peer-reviewed.

Author Contributions: Concept - F.K.; Design - F.K.; Supervision - F.K.; Resources - F.K., N.Y.; Materials - F.K., N.Y.; Data Collection and/or Processing - F.K., N.Y.; Analysis and/or Interpretation F.K.; Literature Search - N.Y.; Writing Manuscript - F.K., N.Y.; Critical Review - F.K., N.Y.; Other - F.K., N.Y.

Conflict of Interest: The authors have no conflicts of interest to declare.

Financial Disclosure: This study was supported by Akdeniz University Scientific Research Projects Unit. (Project Code: TSA2016-1384). 


\section{References}

*The studies included in the meta-analysis

Akça, N., \& Taşçl, S. (2009). Hemşirelik eğitimi ve eleştirel düşünme. Mersin Üniversitesi Eğitim Fakültesi, 5(2), 187-195.

Azizi-Fini, I., Hajibagheri, A., \& Adib-Hajbaghery, M. (2015). Critical thinking skills in nursing students: A comparison between freshmen and senior students. Nursing and Midwifery Studies, 4(1), 1-5. [CrossRef]

Bapoğlu, S. S., Açikgöz, F., Kapisiz, Ö., \& Yilmaz, Ö. (2011). Hemşirelik öğrencilerinin eleştirel düşünme becerilerini geliştirmede drama yönteminin kullanılması. Düzce Üniversitesi, 1(3), 17-21.

*Bilgiç, Ş., \& Kurtuluş Tosun, Z. (2016). Birinci ve Son Sinıf Hemşirelik Öğrencilerinde Eleştirel Düşünme ve Etkileyen Faktörler. Sağlık Bilimleri ve Meslekleri Dergisi, 3(1), 39. [CrossRef]

Bulut, S., Ertem, G., \& Sevil, Ü. (2009). Hemşirelik öğrencilerinin eleştirel düşünme düzeylerinin incelenmesi. Dokuz Eylül Üniversitesi Hemşirelik, 2(2), 27-38.

Carter, A. G., Creedy, D. K., \& Sidebotham, M. (2015). Evaluation of tools used to measure critical thinking development in nursing and midwifery undergraduate students: A systematic review. Nurse Educ Today, 35(7), 864-874. [CrossRef]

Cüceloglu D. (1998). İyi düsün dogru karar ver. (23. Baskl). İstanbul: Sistem Yayıncllı

*Çevik, C., Tekir, Ö., İnceler, K., \& Dikoğlu M. (2014). Sağlkk yüksekokulu öğrencilerinin eleştirel düşünme eğilimlerinin incelenmesi. Uluslararası Hakemli Hemşirelik Araştırmaları Dergisi, 11(1), 11-21.

Çınar, N., Akduran, F., \& Aşkın, M. (2012). Hemşirelik bölümü öğrencilerinin eleştirel düşünme düzeyi ve eleştirel düşünmelerini etkileyen faktörler. Turkiye Klinikleri, 4(1), 8-14.

Dil-Coşkun, S. (2001). Hacettepe Üniversitesi Hemşirelik Yüksekokulu öğrencilerinin eleştirel düşünme düzeyleri. Hacettepe Üniversitesi Sağlık Bilimleri Enstitüsü. Ankara: Yüksek Lisans Tezi.

Dinçer, S. (2014). Eğitim Bilimlerinde Uygulamalı Meta-Analiz (1. basım). Ankara: Pegem Akademi Yayıncllk. [CrossRef]

Durmuş-İskender M. ve Karadağ A. (2015). Hemşirelik son sinıf öğrencilerinin eleştirel düşünme düzeylerinin belirlenmesi, DEUHFED, 8(1), 3-11.

Ennis, R. H. (1991). Critical thinking: A streamlined conception. Teaching Philosophy, 14(1) 5-24. [CrossRef]

*Erdem, E., Bayat, M., Avcı, Ö., Tosun, Ö., \& Seviğ, E. Ü. (2013). Öğrenim yaşantıları süresince hemşirelik öğrencilerinin eleştirel düşünme düzeylerindeki değişim. Dokuz Eylül Üniversitesi Hemşirelik, 6(2), 62-66.

Eren Fidancl, B., Cinar, F. İ., Yıldız, D., Akar, F., Türk, A, Tuncer, S., et al. (2012). Hemşirelik Yüksekokulu öğrencilerinin eleştirel düşünme düzeylerinin ve eleştirel düşünmeyi etkileyen faktörlerin değerlendirilmesi, Gülhane Tıp Dergisi, 54, 35-39.

Güven, M., \& Kürüm, D. (2006). Öğrenme stilleri ve eleştirel düşünme arasındaki ilişkiye genel bir bakış. Sosyal Bilimler Dergisi, 1, 75-90.

İskender, M., \& Karadağ, A. (2015). Hemşirelik son sınıf öğrencilerinin eleştirel düşünme düzeylerinin belirlenmesi. Dokuz Eylül Üniversitesi Hemşirelik, 8(1), 3-11.

*Kanbay, Y., Aslan, Ö., \& Işık, E. (2013). Hemşirelik lisans öğrencilerinin problem çözme ve eleştirel düşünme becerileri. Yükseköğretim ve Bilim, 3(3), 244-251.

Kantek, F., Öztürk, N., \& Gezer, N. (2010). Bir Sağlık Yüksekokulunda Öğrencilerin Eleștirel Düșünme Ve Problem Çözme Becerilerinin İncelenmesi. In International Conference on New Trends in Education and Their Implications (pp. 186190). Antalya.
Kaya, H. (2010). Eleştirel düşünmeye eleştirel bir bakış. FNJN 18 (1), 47-51.

Kaya, H., Şenyuva, E., \& Bodur, G. (2016). Developing critical thinking disposition and emotional intelligence of nursing students: A longitudinal research. Nurse Education Today, 48, 72-77. [CrossRef]

Kermansaravi, F., Navidian, A., Kaykhaei, A., \& Narouie, B. (2012). Critical thinking dispositions among junior, senior and graduate nursing students in Iran. Life Science Journal, 9(3), 1865-1870.

Kim, D., Moon, S., Kim, E., Kim, Y., \& Lee, S. (2014). Nursing students' critical thinking disposition according to academic level and satisfaction with nursing. Nurse Education Today, 34(1), 78-82. [CrossRef]

Kim, K., \& Choi, J. (2014). The relationship between problem solving ability, professional self concept, and critical thinking disposition of nursing students. International Journal of BioScience and Bio-Technology, 6(5), 131-142. [CrossRef]

Kong, L. N., Qin, B., Zhou, Y., Mou, S., \& Gao, H. M. (2014). The effectiveness of problem-based learning on development of nursing students' critical thinking: A systematic review and meta-analysis. International Journal of Nursing Studies, 51(3), 458-469. [CrossRef]

Korkmaz, Ö. (2009). Eğitim fakültelerinin öğrencilerin eleştirel düşünme eğilim ve düzeylerine etkisi. Türk Eğitim Bilimleri Dergisi, 7(4), 879-902.

Kurnaz A. (2011). Eleştirel düşünme öğretimi etkinlikleri: Planlama - uygulama ve değerlendirme. Konya: Eğitim Akademi Yayınevi.

Küçükgüçlü Ö. \& Kanbay Y. (2011). Hemşirelik öğrencilerinin eleştirel düşünme eğilimleri ile klinik başarıları arasındaki ilişkinin incelenmesi. Anadolu Hemşirelik ve Sağlık Bilimleri Dergisi, 14(3), 21-25.

Martin, C. (2002). The theory of critical thinking of nursing. Nursing Education Perspectives, 23(5), 243-247.

Maynard, C. A. (1996). Relationship of critical thinking ability to professional nursing competence. The Journal of Nursing Education, 35(1), 12-18.

Oh, K., Ahn, Y. H., Lee, H. Y., Lee, S. J., Kim, I. J., Choi, K. S., \& Ko, M. S. (2011). A study on Korean nursing students' educational outcomes. Journal of Educational Evaluation for Health Professions, 8, 3. [CrossRef]

Özmen, K. S. (2008). Yüksek eğitimde eleştirel düşünmenin durumu ve anlayışı. Journal of Gazi Educational Faculty, 28(2): 109-127.

*Özpulat F., Bilgen-Sivri, B. (2014). Hemşirelik öğrencilerinin empatik eğilimleri ve eleştirel düşünme becerileri. Uluslararası Hakemli Akademik Spor Sağlık ve Tıp Bilimleri Dergisi, 11(4), 31-49.

*Öztürk, N., \& Ulusoy, H. (2008). Lisans ve yüksek lisans hemşirelik öğrencilerinin eleştirel düşünme düzeyleri ve eleştirel düşünmeyi etkileyen faktörler. Maltepe Üniversitesi Hemşirelik, 1(1), 15-25.

Profetto-McGrath, J. (2003). The relationship of critical thinking skills and critical thinking dispositions of baccalaureate nursing students. Journal of Advanced Nursing, 43(6), 569-577. [CrossRef]

Riddell T. (2007). Critical assumptions: Thinking critically about critical thinking. Journal of Nursing Education, 46(3) 121-126.

Seymour, B., Kinn, S., \& Sutherland, N. (2003). Issues and innovations in nursing practice "Valuing both critical and creative thinking in clinical practice: Narrowing the research- practice gap? Journal of Advanced Nursing, 42(3), 288-302. [CrossRef] 
Shin, K. R., Lee, J. H., Ha, J. Y., \& Kim, K. H. (2006). Critical thinking dispositions in baccalaureate nursing students. Journal of Advanced Nursing, 56(2), 182-189. [CrossRef]

*Şengül, F. (2010). Hemşirelik eğitim modellerinin öğrencilerin eleştirel düşünme eğilimlerine etkisi: Çok merkezli çalışma. (Yüksek Lisans Tezi). Çukurova Üniversitesi Sağlık Bilimleri Enstitüsü, Adana.

Şenturan, I., \& Alpar, Ş. (2008). Hemşirelik öğrencilerinde eleştirel düşünme. Cumhuriyet Üniversitesi Hemşirelik Yüksekokulu Dergisi, 12(1), 22-30.
Yıldırım, B. (2010). Beceri temelli eleştirel düşünme öğretiminin öğrenci hemşirelerde eleştirel düşünme gelişimine etkisi. Ege Üniversitesi Sağllk Bilimleri Enstitüsü. İzmir: Doktora Tezi.

Zangaro, G. A., \& Soeken, K. L. (2007). A meta-analysis of studies of nurses' job satisfaction. Research in Nursing \{g\} Health, 30(4), 445-458. [CrossRef]

*Zaybak, A., \& Khorshid, L. (2006). Ege Üniversitesi Hemşirelik Yüksekokulu öğrencilerinin eleştirel düşünme düzeylerinin incelenmesi. Ege Üniversitesi Hemşirelik Yüksekokulu Dergisi, 22(2), 137-146. 